\title{
Outbreaks of infectious disease associated with private drinking water supplies in England and Wales 1970-2000
}

\author{
B. SAID ${ }^{1 *}$, F. WRIGHT ${ }^{2}$, G. L. NICHOLS ${ }^{1}$, M. REACHER ${ }^{3}$ AND M. RUTTER ${ }^{4}$ \\ ${ }^{1}$ Environmental Surveillance Unit, CDSC, Public Health Laboratory Service, 61 Colindále Avenue, \\ London NW9 $5 E Q$ \\ ${ }^{2}$ East London and The City Health Authority, 81-91 Commercial Road, London E1 1RD \\ ${ }^{3}$ Gastrointestinal Disease Unit, CDSC, Public Health Laboratory Service, 61 Colindale Avenue, \\ London NW9 $5 E Q$ \\ ${ }^{4}$ Environment Law Group, CMS Cameron McKenna, 160 Aldersgate Street, London EC14 4DD
}

(Accepted 27 January 2003)

\section{SUMMARY}

In England and Wales over the last 30 years there have been 25 reported outbreaks of infection, associated with private water supplies (PWS). The majority (16 outbreaks) were reported after the introduction of enhanced surveillance. Although PWS only serve $0.5 \%$ of the population, $36 \%$ of drinking water outbreaks are associated with PWS. The main pathogen, campylobacter, was implicated in $13(52 \%)$ outbreaks. Most reported outbreaks (88\%) occurred in commercial or Category Two supplies, which potentially affect larger populations. The main factors implicated in these outbreaks are temporary or transient populations, treatment (lack or failure), the presence of animals and heavy rains. The public health problem associated with PWS could be prevented by the identification and understanding of risk factors, by the proper protection of water sources and adequate treatment and maintenance. This could be facilitated through the introduction of a risk assessment as part of a scheme for PWS.

\section{INTRODUCTION}

In England and Wales most people receive their domestic drinking water through public or mains water supplies provided by statutorily appointed water undertakers. Private water supplies (PWS) are those provided by someone, other than statutorily appointed water undertaker and approximately 300000 people are in households served by a PWS [1]. There are approximately 50000 registered PWS of which, 30000 serve single dwellings [1]. PWS are categorized and classified according to the volume of water or number of people supplied, and the purposes for which they are used $[2,3]$. The most common sources of PWS are springs, boreholes and wells. Much of the water is

\footnotetext{
* Author for correspondence.
}

consumed without any treatment. PWS are divided into Category One, where water is used for wholly domestic purposes and Category Two supplies, which include uses such as commercial food production and drinking water provision to hospitals and holiday establishments' [3]. Category One supplies are further subdivided in decreasing size as classes A-F depending on the number of people served. Category Two supplies are subdivided in decreasing size as classes 1-5 depending on the quantity of water supplied. Large numbers of people from the wider population are unknowingly exposed to PWS in, for example, hospitals, hotels, holiday homes and campsites. In the United Kingdom $35.7 \%$ of the larger (Category Two) supplies provide water to regularly changing or transient populations [4]. Microbiological contamination is common even though PWS are subject to 
the same regulatory quality standards as public water supplies, including the requirement that coliforms and Escherichia coli should be absent from a $100 \mathrm{ml}$ sample of water $[2,3,5,6]$. In a national survey of PWS in 1996-7, 21\% samples and 33\% of supplies failed current regulations for E. coli on at least one occasion. Total coliforms were detected in $27 \%$ of samples and from $42 \%$ of supplies [7]. In comparison $0 \cdot 1 \%$ and $0.8 \%$ of samples, taken from public water supplies in 1997, were positive for E. coli and coliforms respectively [8].

Outbreaks of waterborne infection occurring in the UK from 1937-95 have previously been reviewed [9-11]. Thirty-four waterborne outbreaks were recorded in the UK in the years 1937-86, of these 13 were attributed to PWS [9]. Before 1980 typhoid, paratyphoid and dysentery were the main diseases causing waterborne outbreaks $[9,11]$. The improvements in water treatment, particularly chlorination, led to the decline of these bacterial pathogens. Since 1980 cryptosporidium has been the main pathogen in waterborne outbreaks associated with public water supplies $[10,11]$. In PWS a variety of pathogens, including giardia, cryptosporidium E. coli $\mathrm{O} 157$ and campylobacter, have been linked to disease as a result of water consumption. Campylobacter was the most commonly identified pathogen in waterborne outbreaks associated with PWS [10]. However, people using PWS reported no more gastrointestinal symptoms than those on the mains supply, although significantly more people with PWS had antibodies to E. coli $\mathrm{O} 157$ and excreted vero-cytotoxigenic E. coli [12]. The contribution of PWS to disease in the general population is difficult to assess despite the association of PWS with outbreaks of typhoid, paratyphoid, amoebiasis and viral gastroenteritis $[9,10]$. This study reviews outbreaks of infectious disease, associated with PWS, reported to the Communicable Disease Surveillance Centre (CDSC) since 1970. The types of PWS, the population served by these supplies, and the possible factors contributing to the outbreaks are described and the public health problem associated with PWS in England and Wales is assessed.

\section{METHODS}

This study confines itself to England and Wales, which form the geographic area covered by the Public Health Laboratory Service (PHLS) CDSC. The study reviews in detail outbreaks of infectious waterborne disease associated with PWS between the years 1970 and 2000. Outbreaks associated with public water supplies over the same period were included for comparison only. Non-potable waters were specifically excluded from this study. A literature search was done on various scientific databases, including Medline, using the terms 'water supply' and 'disease outbreaks'. The terms were combined and limited by English language and year 1970-2002. Papers were screened and relevant data extracted. Data was obtained from published papers, Communicable Disease Reports and from unpublished reports held at CDSC. Much of the detailed information on outbreaks came from unpublished investigators' reports and reporting forms, which are sent as electronic or paper reports to CDSC when an outbreak occurs. In addition Local Authority reports and surveys were used to describe and enumerate PWS, and the population served by them. An outbreak was defined as two or more cases that were linked to a common PWS, although in practice the smallest outbreak involved seven cases. The methods used in the investigations were appraised in relation to epidemiological methods for example, the size and power of the study and the good practice in outbreak investigation. Particular note was taken of the effect these would have on the validity of estimates of case numbers and the wider population at risk.

The strength of evidence that the outbreak was waterborne was assessed using the system published by CDSC [13]. This approach grades epidemiological, environmental and microbiological evidence in suspected waterborne outbreaks. The association is graded, strong, probable or possible.

\section{RESULTS}

\section{Outbreaks associated with drinking water}

Between the years 1970 and 2000 there were 69 reported outbreaks of waterborne disease associated with drinking water; $25(36 \%)$ outbreaks associated with PWS (Table 1) and 44 (64\%) from public water supplies [9-11, 14-40]. The public water supply outbreaks gave rise to more than 8800 cases $[9-11,14-23]$ and were caused by $S$. paratyphi (1 outbreak), campylobacter (4), giardia (1), cryptosporidium (33) and 5 were unknown (possibly viral). More than half (23) public water supply outbreaks occurred after 1991 and $22(96 \%)$ of these were cryptosporidium outbreaks [10, 14-16, 19-20, 22]. 


\section{Outbreaks associated with PWS}

For the 25 outbreaks associated with PWS, investigations identified 1584 cases and at least 5190 people at risk [9-11, 14-40]. Sixteen (64\%) of these outbreaks were reported after the introduction of enhanced surveillance of waterborne outbreaks by CDSC. The epidemiological study design, clinical microbiology, environmental description and microbiological investigation of water are described in all the outbreaks. There is however very little evidence of investigations into epidemiological links to exposures, other than water and illness. Case definition and case findings are also rarely described for these outbreaks. On this evidence the strength of association is strong or probable for $19(76 \%)$ of the 25 outbreaks (Table 1$)$. The numbers of people affected and at risk, in each outbreak, varies and attack rates range from 7-89\% (mean $30 \%$ ). The duration of an outbreak, from day of onset of first case, to day of onset of last case, ranges from 1-175 days (median 8.5 days), with the giardia outbreak (no. 9) having the longest duration.

The most common symptoms were gastrointestinal and there were no recorded secondary cases or deaths, although there were several hospital admissions. There were only two outbreaks in which the main clinical features were not gastrointestinal. The first (no. 1) was an outbreak of paratyphoid fever, affecting two families and requiring the hospitalization of four $(57 \%)$ of the affected individuals. The second was an outbreak (no. 6) of streptobacillary fever, affecting 304 people at a boarding school with symptoms of severe joint pain, anaemia and frequent relapse, which required hospital admission in some cases.

The protozoan pathogens, giardia and cryptosporidium, were implicated in four outbreaks (nos. 9, $10,20,25$ ), each of between 30 and 45 cases, and all having duration of more than 11 days. A mixed outbreak (no. 12) of cryptosporidium and campylobacter affected 43 people, with dual infection identified in two cases [24].

The most commonly identified pathogen was campylobacter causing $13(52 \%)$ outbreaks, including the mixed outbreak. There were 758 cases of gastrointestinal illness, from an estimated population at risk of 2298 people (mean attack rate of $42 \%$ ). The duration of the campylobacter outbreaks ranged from 1-60 days. The only other bacterial pathogen was E. coli O157, which caused outbreak no. 22 in the South West region. The organism was isolated from the PWS and from faecal samples of 10 cases, all children who drank squash diluted with PWS water; one child developed haemolytic uraemic syndrome [25]. No pathogens were identified in four of the outbreaks (nos. 2, 3, 5, 21) despite microbiological investigation. Viral agents were implicated in outbreak no. 17, although both giardia (two cases) and campylobacter (two cases) were isolated, and the causative agent was not established. The outbreaks, of unknown causation, account for nearly 400 cases of gastrointestinal illness.

\section{PWS}

The characteristics of PWS linked with the outbreaks are described in Table 1. Twenty-two of the 25 outbreaks $(88 \%)$ were in Category Two supplies and the remaining three outbreaks occurred in Category One/class F supplies or single domestic dwellings. The latter accounted for 29 cases with 46 people at risk ( $63 \%$ mean attack rate) and involved severe bacterial infections with Salmonella paratyphi B (no. 1), Campylobacter sp. (no. 11) and E. coli O157 (no. 22). In comparison, Category Two outbreaks accounted for 1555 cases with 5144 people estimated to be at risk (30\% mean attack) and were predominantly associated with campylobacter and cryptosporidium. The most common PWS source was a spring, linked with $14(56 \%)$ outbreaks. Other sources were; stream or surface water ( 5 outbreaks), well (4 outbreaks), borehole ( 3 outbreaks) and 1 of unknown source. Two supplies were not strictly from PWS; the boarding school in outbreak no. 4 was served both by a borehole with an open storage tank and mains water, and the farm in outbreak no. 20 used public water, which came through a private pipe and was stored in a tank.

\section{Factors implicated in outbreaks associated with PWS}

Several contributing factors are implicated in the outbreaks (Table 1). The single most common factor was the transient nature of populations affected by these outbreaks. Twenty-one outbreaks occurred in establishments, such as boarding schools and holiday homes, where the individuals contracting the disease were not permanent residents. In a further two outbreaks (nos. 20 and 23) it was unclear if the affected people were permanent residents or not. In one outbreak (no. 22) the people were new owners holding a birthday party for a child and unaware that they were on a private supply [25]. Therefore in $88 \%$ of the outbreaks it was transitory or temporarily resident 
Table 1. Outbreaks of infectious disease associated with private drinking water supplies in England and Wales 1970-2000

\begin{tabular}{|c|c|c|c|c|c|c|c|c|c|c|}
\hline $\begin{array}{l}\text { Out- } \\
\text { break }\end{array}$ & Date & Region & $\begin{array}{l}\text { No. affected/ } \\
\text { at risk } \\
\text { (attack rate) }\end{array}$ & Pathogen & Association & $\begin{array}{l}\text { Estab- } \\
\text { lishment }\end{array}$ & $\begin{array}{l}\text { Water } \\
\text { source }\end{array}$ & $\begin{array}{l}\text { Category/ } \\
\text { class }\end{array}$ & Treatment & $\begin{array}{l}\text { Implicated factors } \\
\text { [reference] }\end{array}$ \\
\hline 1 & $\begin{array}{l}\text { July } \\
1975\end{array}$ & Herefordshire & $7 / 10(70 \%)$ & $\begin{array}{l}\text { Salmonella } \\
\text { paratyphi B } \\
\text { (PT1) }\end{array}$ & Probable & $\begin{array}{r}\text { Private } \\
\text { house }\end{array}$ & $\begin{array}{l}\text { Well and } \\
\text { storage } \\
\text { tank }\end{array}$ & One $/ F$ & $\begin{array}{l}\text { Probably } \\
\text { untreated }\end{array}$ & $\begin{array}{l}\text { Possible leakage from } \\
\text { private sewage system. } \\
\text { Poorly maintained } \\
\text { well }[9,11,27,40]\end{array}$ \\
\hline 2 & $\begin{array}{l}\text { August } \\
1980\end{array}$ & Somerset & $160 / 316(50 \%)$ & Unknown & Possible & $\begin{array}{r}\text { Holiday } \\
\text { hamlet }\end{array}$ & $\begin{array}{l}\text { Spring and } \\
\text { collection } \\
\text { tank }\end{array}$ & Two $/ 3$ & Chlorinated & $\begin{array}{l}\text { Probable chlorination } \\
\text { failure as } E \text {. coli in } \\
\text { supply }[9,11,28,40]\end{array}$ \\
\hline 3 & $\begin{array}{l}\text { September } \\
1980\end{array}$ & Somerset & $12 / ?(?)$ & Unknown & Possible & $\begin{array}{r}\text { Holiday } \\
\text { hamlet }\end{array}$ & $\begin{array}{l}\text { Spring and } \\
\text { collection } \\
\text { tank }\end{array}$ & Two $/ 3$ & Chlorinated & $\begin{array}{l}\text { Probable chlorination } \\
\text { failure as } E \text {. coli in } \\
\text { supply }[28,40]\end{array}$ \\
\hline 4 & $\begin{array}{l}\text { May } \\
1981\end{array}$ & Essex & $257 / 700(40 \%)$ & Campylobacter & Strong & $\begin{array}{l}\text { Boarding } \\
\text { school }\end{array}$ & $\begin{array}{l}\text { Borehole } \\
\text { with open } \\
\text { storage tank } \\
\text { and mains } \\
\text { water }\end{array}$ & Two $/ 2$ & Untreated & $\begin{array}{l}\text { Work undertaken } \\
\text { near storage } \\
\text { tank. Possible } \\
\text { contamination from } \\
\text { roosting birds and } \\
\text { bats }[9,11,29,40]\end{array}$ \\
\hline 5 & $\begin{array}{l}\text { July } \\
1982\end{array}$ & Derbyshire & 138/? ('high') & Unknown & Possible & $\begin{array}{l}\text { Youth } \\
\text { hostel }\end{array}$ & $\begin{array}{c}\text { Surface } \\
\text { water }\end{array}$ & $\begin{array}{c}\text { Two } / 2 \\
\text { or } 3\end{array}$ & $\begin{array}{l}\text { Chlorination } \\
\text { and sand } \\
\text { filter }\end{array}$ & $\begin{array}{l}\text { Dry weather led to } \\
\text { low flow in streams } \\
\text { and perhaps higher } \\
\text { concentrations of } \\
\text { organic matter } \\
{[9,11,30,40]}\end{array}$ \\
\hline 6 & $\begin{array}{l}\text { February } \\
1983\end{array}$ & Essex & $304 / 700(47 \%)$ & $\begin{array}{l}\text { Streptobacillus } \\
\text { moniliformis }\end{array}$ & Strong & $\begin{array}{l}\text { Boarding } \\
\text { school }\end{array}$ & $\begin{array}{l}\text { Well fed } \\
\text { from } \\
\text { spring }\end{array}$ & Two $/ 2$ & $\begin{array}{l}\text { Chlorination } \\
\text { and } \\
\text { calorifiers }\end{array}$ & $\begin{array}{l}\text { Rats in spring } \\
\text { and sewer. Inadequate } \\
\text { chlorination and } \\
\text { heating of water. } \\
\text { Building works led to } \\
\text { disconnection of } \\
\text { mains. Storms } \\
\text { disturbed rat } \\
\text { population } \\
{[9,11,31-35,40]}\end{array}$ \\
\hline
\end{tabular}


Two $/ 2$ or 3

Chlorination

or 3

Untreated

November West

$1991 \quad$ Midlands

$31 / 260(12 \%) \quad$ Giardia

$\begin{array}{lr}\text { April } & \text { North } \\ 1992 & \text { West }\end{array}$

$45 / 650(7 \%)$

Crypto-

sporidium

Strong

Village

Spring

(covered

chamber and

One/C

(village)

Two $/ 4$

reservoir)

(school)

Chlorination

Possible

$\begin{array}{llc}\text { April } & \text { Cumbria } & 8 / 20 ?(40 \%) \\ 1993 & & \\ \text { May } & \begin{array}{c}\text { Northumber } \\ \text { land }\end{array} & 43 / 200(22 \%) \\ 1993 & (70 \% \text { students })\end{array}$

Campylobacter

Crypto-

sporidium and
Campylobacter

\section{Possible}

Probable
Boarding

school

Spring (feeds

reservoir

and storage

tanks)

Two $/ 2$

\section{Chlorination \\ and sand \\ filter}

$\begin{array}{ll}\begin{array}{c}\text { Private } \\ \text { house }\end{array} & \text { Unknown } \\ \begin{array}{ll}\text { Student } \\ \text { residence }\end{array} & \begin{array}{l}\text { Spring } \\ \text { (pipes to } \\ \text { storage } \\ \text { chambers) }\end{array}\end{array}$

$\begin{array}{ll}\text { One } / F & \text { Untreated } \\ \text { Two } / 4 & \text { UV light } \\ \text { and } & \text { and filters } \\ \text { One } / \mathrm{C} & \end{array}$

Surrounded by

pasture. Chlorination possibly inadequate.

Recent Snow-melt,

therefore, run-off

from fields and higher

flow $[9,11,40]$

Sheep grazing near

streams and well.

Poultry faeces found

on well cover and

birds feeding near

churn. Base of well

cracked. Heavy

rains $[9,11,36,40]$

Heavy rains. Sheep and

horse grazing near

spring source.

Chlorination

inadequate $[10,11]$

Cattle and sheep out to

graze and slurry

spread near reservoir

just prior to outbreak.

Inadequate chlorine

levels. Increased

demand at term start

[10, 11]

On farmland. Proximity

of animals not known

$[10,11]$

Heavy rainfall. Slurry

distributed prior to

outbreak. Connection

accidentally renewed

to disused chamber in

which dead lambs

found. UV light

renewed but tube

clouded over

$[10,11,24]$ 
Table 1 (cont.)

\begin{tabular}{|c|c|c|c|c|c|c|c|c|c|c|}
\hline $\begin{array}{l}\text { Out- } \\
\text { break }\end{array}$ & Date & Region & $\begin{array}{l}\text { No. affected/ } \\
\text { at risk } \\
\text { (attack rate) }\end{array}$ & Pathogen & Association & $\begin{array}{l}\text { Estab- } \\
\text { lishment }\end{array}$ & $\begin{array}{l}\text { Water } \\
\text { source }\end{array}$ & $\begin{array}{l}\text { Category/ } \\
\text { class }\end{array}$ & Treatment & $\begin{array}{l}\text { Implicated factors } \\
\text { [reference] }\end{array}$ \\
\hline 13 & $\begin{array}{l}\text { September } \\
1993\end{array}$ & $\begin{array}{l}\text { North } \\
\text { West }\end{array}$ & $39 / 600(7 \%)$ & Campylobacter & Strong & $\begin{array}{l}\text { Boarding } \\
\text { school }\end{array}$ & $\begin{array}{l}\text { Spring } \\
\text { (feeds } \\
\text { reservoir } \\
\text { and storage } \\
\text { tanks) }\end{array}$ & Two $/ 2$ & $\begin{array}{l}\text { Chlorination } \\
\text { and sand } \\
\text { filtration }\end{array}$ & $\begin{array}{l}\text { Fence erected since } \\
\text { previous outbreak } \\
\text { (no. 10) had fallen. } \\
\text { Chlorination } \\
\text { inadequately } \\
\text { maintained in } \\
\text { holidays. Start of } \\
\text { term again }[10,11]\end{array}$ \\
\hline 14 & $\begin{array}{l}\text { April } \\
1994\end{array}$ & Norfolk & $53 / 127(43 \%)$ & Campylobacter & Strong & $\begin{array}{l}\text { Residential } \\
\text { hall }\end{array}$ & $\begin{array}{l}\text { Spring to } \\
\text { water tower }\end{array}$ & Two $/ 3$ & $\begin{array}{l}\text { Sand filtration } \\
\text { and UV } \\
\text { light }\end{array}$ & $\begin{array}{l}\text { Animals near spring } \\
\text { source. Holes in cover } \\
\text { of water tower and } \\
\text { spring allowed debris } \\
\text { and birds to enter. } \\
\text { Water tower had not } \\
\text { been cleaned recently. } \\
\text { UV lights expired and } \\
\text { clouded over. Recent } \\
\text { heavy rains and } \\
\text { increase in demand } \\
{[10,11,37]}\end{array}$ \\
\hline 15 & July 1994 & North & $8 / 9(89 \%)$ & Campylobacter & Strong & $\begin{array}{l}\text { Guest } \\
\text { house }\end{array}$ & $\begin{array}{l}\text { Stream } \\
\text { and tanks }\end{array}$ & Two $/ 5$ & $\begin{array}{l}\text { Coarse } \\
\text { filtration } \\
\text { (gravel beds) }\end{array}$ & $\begin{array}{l}\text { Untreated surface } \\
\text { water supply } \\
{[10,11,37]}\end{array}$ \\
\hline 16 & $\begin{array}{l}\text { October } \\
1994\end{array}$ & Wales & $22 / 24(28 \%)$ & Campylobacter & Strong & $\begin{array}{l}\text { Adventure } \\
\text { centre }\end{array}$ & Spring & Two/4 & $\begin{array}{l}\text { Untreated } \\
\text { (part of } \\
\text { supply- } \\
\text { UV light) }\end{array}$ & $\begin{array}{l}\text { Sheep grazing near } \\
\text { water source were } \\
\text { recently given } \\
\text { laxatives to eliminate } \\
\text { parasites ('drenching'). } \\
\text { UV light failed (but } \\
\text { distal to where most } \\
\text { water drawn). Fine } \\
\text { weather [10,11,37] }\end{array}$ \\
\hline
\end{tabular}




\begin{tabular}{|c|c|c|c|c|c|c|c|c|c|c|}
\hline 17 & $\begin{array}{l}\text { May } \\
1995\end{array}$ & $\begin{array}{l}\text { East } \\
\text { Anglia }\end{array}$ & $58 / 700(8 \%)$ & Unknown & Probable & $\begin{array}{l}\text { Research } \\
\text { institute } \\
\text { and rural } \\
\text { village }\end{array}$ & $\begin{array}{l}\text { Two boreholes } \\
\text { used alternate } \\
\text { weeks feed } \\
\text { into holding } \\
\text { tanks }\end{array}$ & Two $/ 2$ & Chlorination & $\begin{array}{l}\text { Private sewage } \\
\text { treatment work. } \\
\text { Animal, human } \\
\text { and chemical waste } \\
\text { near one borehole. } \\
\text { Construction work } \\
\text { above ground over } \\
\text { sewers, and evidence } \\
\text { of sewer leaking. } \\
\text { Dry weather } \\
{[10,11,14,26]}\end{array}$ \\
\hline 18 & $\begin{array}{l}\text { July } \\
1997\end{array}$ & Devon & 16/? (?) & Campylobacter & Probable & $\begin{array}{l}\text { Expedition } \\
\text { training } \\
\text { centre }\end{array}$ & $\begin{array}{c}\text { Surface } \\
\text { water }\end{array}$ & Two/? & $\begin{array}{l}\text { Treated } \\
\text { (method } \\
\text { unknown) }\end{array}$ & $\begin{array}{l}\text { Sheep and cattle } \\
\text { grazing near } \\
\text { source. Treatment } \\
\text { facility inadequately } \\
\text { maintained }[17,39]\end{array}$ \\
\hline 19 & $\begin{array}{l}\text { April } \\
1998\end{array}$ & Wales & $11 / 250(4 \%)$ & Campylobacter & Probable & $\begin{array}{l}\text { Training } \\
\text { centre }\end{array}$ & $\begin{array}{l}\text { Borehole } \\
\text { or spring }\end{array}$ & $\begin{array}{l}\text { Two/3 } \\
\text { (or } \\
\text { bigger) }\end{array}$ & Filtration & $\begin{array}{l}\text { Designated and } \\
\text { non-designated } \\
\text { drinking sites } \\
\text { contaminated } \\
\text { on many previous } \\
\text { occasions }[20,39]\end{array}$ \\
\hline 20 & $\begin{array}{l}\text { April } \\
1998\end{array}$ & Lancashire & 24/? (?) & $\begin{array}{l}\text { Crypto- } \\
\text { sporidium }\end{array}$ & Strong & Farm & $\begin{array}{l}\text { Mains } \\
\text { water } \\
\text { through } \\
\text { private } \\
\text { pipe to } \\
\text { tank }\end{array}$ & Two $/ 3$ & Unknown & $\begin{array}{l}\text { Water tank in very } \\
\text { poor state of } \\
\text { structural repair. } \\
\text { Sheep and sheep } \\
\text { droppings on } \\
\text { tank }[18,20]\end{array}$ \\
\hline 21 & $\begin{array}{l}\text { May } \\
1998\end{array}$ & Devon & $25 / 52(48 \%)$ & Unknown & Probable & $\begin{array}{l}\text { Training } \\
\text { 'hut' }\end{array}$ & $\begin{array}{l}\text { Unauthorized } \\
\text { (?surface) } \\
\text { water }\end{array}$ & Two/? & $\begin{array}{l}\text { Chlorination } \\
\text { and } \\
\text { filtration }\end{array}$ & $\begin{array}{l}\text { Inadequate } \\
\text { chlorination. } \\
\text { High coliform } \\
\text { counts }[19,20]\end{array}$ \\
\hline 22 & $\begin{array}{l}\text { June } \\
1998\end{array}$ & Dorset & $14 / 16(87 \%)$ & E. coli $\mathrm{O} 157$ & Strong & Farm & $\begin{array}{l}\text { Tap water, } \\
\text { private from } \\
\text { well }\end{array}$ & One/F? & Untreated & $\begin{array}{l}\text { Pathogen identified } \\
\text { in water and from } \\
\text { cases. Children had } \\
\text { drunk squash diluted } \\
\text { with water. New } \\
\text { owners unaware of } \\
\text { private supply. } \\
\text { Zoonotic } \\
\text { contamination } \\
{[18,20,25]}\end{array}$ \\
\hline
\end{tabular}


Table 1 (cont.)

\begin{tabular}{|c|c|c|c|c|c|c|c|c|c|c|}
\hline $\begin{array}{l}\text { Out- } \\
\text { break }\end{array}$ & Date & Region & $\begin{array}{l}\text { No. affected/ } \\
\text { at risk } \\
\text { (attack rate) }\end{array}$ & Pathogen & Association & $\begin{array}{l}\text { Estab- } \\
\text { lishment }\end{array}$ & $\begin{array}{l}\text { Water } \\
\text { source }\end{array}$ & $\begin{array}{l}\text { Category/ } \\
\text { class }\end{array}$ & Treatment & $\begin{array}{l}\text { Implicated factors } \\
\text { [reference] }\end{array}$ \\
\hline 23 & $\begin{array}{l}\text { July } \\
1998\end{array}$ & Yorkshire & $20 / 27(74 \%)$ & Campylobacter & Probable & Farm & Stream & Two/? & UV & $\begin{array}{l}\text { Failure of UV bulb } \\
\text { renewal in water } \\
\text { treatment apparatus } \\
\text { (due Aug. 97). Water } \\
\text { samples severely } \\
\text { contaminated } \\
{[19,20,39]}\end{array}$ \\
\hline 24 & $\begin{array}{l}\text { August } \\
1999\end{array}$ & Yorkshire & $18 / 24(75 \%)$ & Campylobacter & Strong & $\begin{array}{l}\text { Holiday } \\
\text { cottages }\end{array}$ & Spring & Two/? & Untreated & $\begin{array}{l}\text { High coliform counts } \\
\text { in water samples. } \\
\text { Epidemiological } \\
\text { association with } \\
\text { private supply; } \\
\text { C. jejuni HS50 } \\
\text { PT35 identified from } \\
\text { water and cases } \\
{[21,22,39]}\end{array}$ \\
\hline 25 & $\begin{array}{l}\text { May } \\
2000\end{array}$ & $\begin{array}{l}\text { South } \\
\text { West }\end{array}$ & $8 / 14(57 \%)$ & $\begin{array}{l}\text { Crypto } \\
\text { sporidium }\end{array}$ & Possible & $\begin{array}{l}\text { Farm } \\
\text { holiday } \\
\text { centre }\end{array}$ & $\begin{array}{l}\text { Spring } \\
\text { or well }\end{array}$ & Two/? & $\begin{array}{l}\text { Partially or } \\
\text { incompletely } \\
\text { treated (?) }\end{array}$ & $\begin{array}{l}\text { Indicator organism } \\
\text { in PWS, but no } \\
\text { cryptosporidium } \\
\text { detected. (Infected } \\
\text { children also had } \\
\text { recreational exposure } \\
\text { to nearby stream and } \\
\text { play on nearby } \\
\text { meadows used for } \\
\text { grazing.) }[22,23]\end{array}$ \\
\hline
\end{tabular}


populations newly exposed to the PWS that were affected.

Another commonly implicated factor, described in $80 \%$ of PWS associated with outbreaks, is failure or lack of treatment. Seven of the PWS were untreated, including all three of the Category One supplies. Thirteen PWS cited failure of treatment or inadequate treatment as a factor implicated in the outbreak.

Other recurring factors were: the presence of animals, in particular grazing livestock, or slurry spreading indicated in $13(52 \%)$ outbreaks; poor maintenance or building works described in $7(28 \%)$; and heavy rains preceding or concurrent with the outbreak in $6(24 \%)$. Information on the monitoring of the PWS was not readily available. Where information was given, the sample taken prior to an outbreak was as likely to have been satisfactory, as it was to have been contaminated. Control measures were described for 18 of the 25 outbreaks and these ranged from 'boil water' notices to complete overhaul of the supply or connection to the mains. However, control measures were not always effective as shown by two sites where repeat outbreaks occurred. The outbreaks (nos. 2, 3) at a holiday hamlet were only one month apart and may have been a recurrence of the same unknown pathogen. The outbreaks at the boarding school (nos. 10,13) were over a year apart and attributed to different causative organisms, cryptosporidium in the spring and campylobacter in the summer of the following year.

\section{DISCUSSION}

Waterborne disease is a worldwide public health problem and a major cause of morbidity and mortality. In England and Wales the majority of people are fortunate in the provision and quality of their drinking water. However, more than a third of a million people use PWS, many of which are of poor microbiological quality [4, 5, 7]. This review describes outbreaks of waterborne disease associated with PWS over a 30 -year period and updates previous reviews [9-11]. The evidence for each outbreak was assessed systematically [13] and the strength of association (Table 1) was strong or probable in $76 \%$ of outbreaks. PWS serve around $300000(0.5 \%$ of the total population of England and Wales) people but are associated with $25(36 \%)$ of drinking water outbreaks, in comparison the remaining population of England and Wales (around 53 million or 99.5\%) are served by public water supplies, which are only associated
$44(64 \%)$ outbreaks. The disease burden therefore falls heavily on those served by or exposed to PWS, suggesting a significant public health problem associated with PWS. Most outbreaks were reported in the 10 years after the introduction of enhanced surveillance suggesting under-ascertainment of outbreaks before this. In addition small outbreaks associated with PWS probably continue to be under-recognized and are likely to be more common than suggested by national outbreak reports $[4,41]$.

Campylobacter were the pathogens most frequently associated with PWS outbreaks in the last 30 years. Since the 1980's campylobacter has been the most common bacterial enteric pathogen in England and Wales [38, 42]. A recent review of campylobacter outbreaks between 1995 and 1999 describes 50 campylobacter outbreaks of which only four $(8 \%)$ were waterborne [39]. All four (also in this review as outbreak nos. 18, 19, 23, 24) were associated with PWS. Investigating campylobacter outbreaks is difficult and made even more so as more than one strain of campylobacter and more than one pathogen may be isolated from a suspect source [24, 39].

It is also difficult to demonstrate an association between the type of drinking water an illness. For example: a case-control study of rural (PWS) families in Oxfordshire matched with families served by a public supply found no consistent differences in the health status of the two groups [43]; and another study examined the cases of campylobacter infection and cryptosporidiosis in ten local authorities but found no difference in disease rates for these pathogens per head of population served by PWS, compared with the general population and therefore concluded that the disease burden due to PWS is small [40]. In contrast a survey of local authorities in the UK found that one third of waterborne infection could be attributed to consumption from PWS. However less than a quarter of local authorities reported such incidents even though the risk of contracting disease from PWS was estimated to be 22 times that from public water [4]. In addition the IID study established that people with gastrointestinal illness often do not seek medical attention and therefore only the minority of cases are actually seen [42]. To compound the difficulties, under-reporting of outbreaks of disease due to PWS may occur for a variety of reasons including; mild illness, small numbers of people affected, dispersal of cases (before people become ill), transient populations, and poor laboratory detection of some infections (e.g. cryptosporidium and campylobacter in the 1970s and 
1980s). Therefore, the true burden of disease is difficult to estimate.

The most common PWS class in England and Wales are the small Category One/class F supplies [5]. However $88 \%$ of the reported outbreaks were associated with Category Two or commercial supplies. These are of concern as commercial supplies are used by transient populations and potentially affect larger numbers of people. The types of Category Two supplies associated with the outbreaks involve sizeable groups of people in temporary residence (e.g. boarding schools, holiday homes) and an outbreak is more likely to be noticed and therefore reported. In contrast Category One supplies serve smaller numbers of people and mainly permanent residents. People continuously served by untreated PWS may be exposed to pathogens (or infected with them) early in life and have a degree of immunity. If this is the case then childhood infections in Category One supplies might be expected to be more common. All three outbreaks in Category One/class F supplies described in this review had serious clinical presentations with a high attack rate and involved children.

The success of water treatment programmes, particularly chlorination, in public water supplies led to the decline of waterborne bacterial diseases. Recent outbreaks are associated with cryptosporidium, an organism resistant to chlorine, or with treatment failure. The principal form of treatment described for PWS associated with the 25 outbreaks was chlorine, either on its own or in combination. However the treatment failed in $13(52 \%)$ and a further $7(28 \%)$ of the PWS, including all 3 of the Category One supplies, were untreated. Other commonly implicated factors were, the potential contamination from grazing animals or slurry spreading, poor maintenance of the supply, and heavy rain, which preceded a quarter of the outbreaks. These factors have all been previously described $[4,7,23,44]$ but a better understanding of the factors contributing to, and the link between, contamination and outbreaks in PWS is needed to provide a good evidence-base for adequate risk assessment.

The contamination of PWS is intermittent and affected by multiple factors and the contamination rates can vary between 20 and $70 \%$ [7, 14-23, 44]. The monitoring of PWS is therefore problematic, and it is difficult to obtain good test samples especially in smaller supplies, which are infrequently monitored. There was little information available on the monitoring of the 25 PWS associated with the outbreaks described in this review. Where information was given, the sample taken prior to an outbreak was as likely to have been satisfactory, as it was to have been contaminated. Monitoring, without action, does not prevent outbreaks. For example, the youth hostel associated with outbreak no. 5 had indicator organisms present and reported in two consecutive years during July and August, with no apparent implementation of long-term improvement. The monitoring of PWS, under the current regulations, is inadequate and inconclusive and could be improved with the introduction of risk assessments. The serious consequences of inadequate monitoring and control have recently been demonstrated in North America and Canada where two outbreaks of E. coli O157, affected more than 6000 people causing 8 deaths [45-48]. The importance of secure water sources and adequate water treatment in ensuring the safety of water supplies cannot be over-emphasized.

In conclusion, the number of cases and outbreaks associated with PWS and therefore the public health problem is probably underestimated. The commercial use of PWS potentially exposes larger populations to the risk of illness through contaminated water from PWS. Identification of risk factors, proper protection of water sources, and adequate treatment and maintenance are essential to protect these populations.

\section{ACKNOWLEDGEMENTS}

The authors would like to acknowledge Mrs Sue Le Baigue for entering the data, and Dr Morag Chisholm, Dr Kim Shepherd and Professor Peter WynJones for their scientific contributions.

\section{REFERENCES}

1. Drinking water inspectorate report. Private water supplies, chapter 4. In: Drinking water 1998. London: HMSO, 1999.

2. Water Industry Act 1991. London: HMSO, 1991.

3. The Private Water Supplies Regulations 1991. Statutory instrument No. 2790. London: HMSO, 1991.

4. Shepherd KM, Wyn-Jones AP. Private water supplies and the local authority role: results of a UK national survey. Wat Sci Tech 1997; 35: 41-5.

5. Drury D. Private water supplies: classification and monitoring. CDR 1995; 5: R98-9.

6. The Water Supply (Water Quality) Regulations 2000. Statutory instrument No. 3184. London: HMSO, 2000.

7. Rutter M, Nichols GL, Swan A, De Louvois J. A survey of the microbiological quality of private water supplies in England. Epidemiol Infect 2000; 124: 417-25. 
8. Chief Inspector Drinking Water Inspectorate. Drinking water 1997. London: HMSO, 1998.

9. Galbraith NS, Barrett NJ, Stanwell-Smith RE. Water and disease after Croydon - A review of water-borne and water-associated disease in the UK 1937-1986. J Inst Wat Environ Mgt 1987; 1: 7-21.

10. Furtado C, Adak GK, Stuart JM, Wall PG, Evans HS, Casemore DP. Outbreaks of waterborne infectious intestinal disease in England and Wales, 1992-5. Epidemiol Infect 1998; 121: 109-19.

11. Hunter PR. Drinking water and waterborne disease. In: Waterborne disease: epidemiology ecology. Chichester: John Wiley \& sons Ltd, 1997: 25-41.

12. Chalmers RM, Aird H, Bolton FJ. Waterborne Escherichia coli O157. J Appl Microbiol 2000; 88: 124S-32S.

13. Tillett HE, de Louvois J, Wall PG. Surveillance of outbreaks of waterborne infectious disease: categorizing levels of evidence. Epidemiol Infect 1998; 120: 37-42.

14. CDSC. Surveillance of waterborne disease and water quality. CDR 1996; 6.

15. CDSC. Surveillance of waterborne disease and water quality. CDR 1996; 6.

16. CDSC. Surveillance of waterborne disease and water quality. CDR 1997; 7.

17. CDSC. Surveillance of waterborne disease and water quality. CDR 1998; 8.

18. CDSC. Surveillance of waterborne disease and water quality. CDR 1998; 8.

19. CDSC. Surveillance of waterborne disease and water quality. CDR 1999; 9.

20. CDSC. Surveillance of waterborne disease and water quality. CDR 1999; 9.

21. CDSC. Surveillance of waterborne disease and water quality. CDR 2000; 10.

22. CDSC. Surveillance of waterborne disease and water quality. CDR 2000; 10.

23. CDSC. Surveillance of waterborne disease and water quality. CDR 2001; 11.

24. Duke LA, Breathnach AS, Jenkins DR, Harkis BA, Codd AW. A mixed outbreak of cryptosporidium and campylobacter infection associated with a private water supply. Epidemiol Infect 1996; 116: 303-8.

25. CDSC. Outbreak of vero cytotoxin producing Escherichia coli O157 infection in Dorset. CDR 1998; 8: 183-6.

26. Reacher M, Ludlam H, Irish N, Buttery R, Murray V. Outbreak of gastroenteritis associated with contamination of a private borehole water supply. CDPH 1999; 2: 27-31.

27. CDSC. Paratyphoid in Herefordshire. CDR 1975; 29.

28. CDSC. Outbreak of gastroenteritis in a holiday camp in Somerset. CDR 1980; 80.

29. Palmer SR, Gully PR, White JM, et al. Waterborne outbreak of campylobacter gastroenteritis. Lancet 1983; i: $287-90$.
30. CDSC. Gastrointestinal illness at a youth hostel: Derbyshire. CDR 1982; 31.

31. McEvoy MB, Noah ND, Pilsworth R. Outbreak of fever caused by Streptobacillus moniliformis. Lancet 1987; ii: 1361-3.

32. Shanson DC, Gazzard BG, Midgeley J, et al. Streptobacillus moniliformis isolated from blood in four cases of Haverhill fever. Lancet 1983; ii : 92-4.

33. CDSC. Boarding school outbreak: Chelmsford. CDR $1983 ; 7$.

34. CDSC. Boarding school outbreak: Chelmsford. CDR $1983 ; 9$.

35. CDSC. Streptobacillary fever: Chelmsford. CDR 1983; 11.

36. CDSC. Campylobacter: An unwelcome camper. CDR 1986, 43.

37. Djuretic T, Wall PG, Ryan MJ, et al. General outbreaks of infectious intestinal disease in England and Wales 1992 to 1994 . CDR 1996; 6: R58-63.

38. Pearson AD, Healing TD. The surveillance and control of Campylobacter infection. CDR 1992; 12: R133-9.

39. Frost JA, Gillespie IA, O'Brien SJ. Public health implications of campylobacter outbreaks in England and Wales, 1995-9: epidemiological and microbiological investigations. Epidemiol Infect 2002; 128: 111-8.

40. Fewtrell L, Kay D. Health risks from private water supplies. University of Leeds: Centre for research and environment, 1996.

41. Hunter PR, Syed Q, Naumova EN. Possible undetected outbreaks of cryptosporidiosis in areas of the North West of England supplied by an unfiltered surface water source. CDPH 2001; 4: 136-8.

42. IID study teams. A report of the study of infectious intestinal disease in England. Food standards agency. London: HMSO, 2000.

43. Meara JR. An investigation of health and lifestyle in people who have private water supplies at home. Commun Med 1989; 11: 131-9.

44. Fewtrell L, Kay D, Godfree A. The microbiological quality of private water supplies. J Chart Inst Wat Environ Mgt 1998; 12: 45-7.

45. Anonymous. Outbreak of Escherichia coli O157:H7 and Campylobacter among attendees of the Washington Country Fair - New York, 1999. MMWR 1999; 48: 803-5.

46. Kondro W. Canada reacts to water contamination. Lancet $2000 ; 355: 2228$.

47. Spurgeon D. Budget cuts may have led to E. coli outbreak. BMJ 2000; 320: 1625.

48. Waterborne outbreak of gastroenteritis associated with a contaminated municipal water supply, Walkerton, Ontario, May-June 2000. Canadian Commun Dis Rep, October $2000 ; 26-20$. 